University of Nebraska - Lincoln

DigitalCommons@University of Nebraska - Lincoln

Agronomy \& Horticulture - Faculty Publications

Agronomy and Horticulture Department

2016

\title{
Estimation of the Degree of Diversity for Some Iraqi Wheat Varieties through ISSR, SRAP and RAPD Markers
}

\author{
Dhafir H. Al-Kaab \\ University of Baghdad \\ Majid Sh. Hamdalla \\ University of Baghdad, Baghdad, Iraq \\ Ismail M. Dweikat \\ University of Nebraska-Lincoln, idweikat2@unl.edu \\ Noora J. Al-Saedi \\ University of Baghdad, Baghdad, Iraq
}

Follow this and additional works at: https://digitalcommons.unl.edu/agronomyfacpub

Part of the Agricultural Science Commons, Agriculture Commons, Agronomy and Crop Sciences Commons, Botany Commons, Horticulture Commons, Other Plant Sciences Commons, and the Plant Biology Commons

Al-Kaab, Dhafir H.; Hamdalla, Majid Sh.; Dweikat, Ismail M.; and Al-Saedi, Noora J., "Estimation of the Degree of Diversity for Some Iraqi Wheat Varieties through ISSR, SRAP and RAPD Markers" (2016). Agronomy \& Horticulture -- Faculty Publications. 884.

https://digitalcommons.unl.edu/agronomyfacpub/884

This Article is brought to you for free and open access by the Agronomy and Horticulture Department at DigitalCommons@University of Nebraska - Lincoln. It has been accepted for inclusion in Agronomy \& Horticulture -Faculty Publications by an authorized administrator of DigitalCommons@University of Nebraska - Lincoln. 


\title{
Estimation of the Degree of Diversity for Some Iraqi Wheat Varieties through ISSR, SRAP and RAPD Markers
}

\author{
Dhafir H. Al-Kaab ${ }^{{ }^{\star}}$, Majid Sh. Hamdalla ${ }^{1}$, Ismail Dweikat ${ }^{2}$ \\ and Noora J. Al-Saedi ${ }^{3}$ \\ ${ }^{1}$ Department of Field Crop, University of Baghdad, Baghdad, Iraq. \\ ${ }^{2}$ Department of Agronomy and Horticulture, University of Nebraska, Lincoln, USA. \\ ${ }^{3}$ Department of Horticulture, University of Baghdad, Baghdad, Iraq.
}

\begin{abstract}
Authors' contributions
This work was carried out in collaboration between all authors. Author MSH designed the study. Author ID wrote the protocol. Authors NJAS and DHAK performed the experiments. Author DHAK wrote the first draft of the manuscript and performed the statistical analysis. All authors read and approved the final manuscript.
\end{abstract}

Article Information

DOI: $10.9734 / A J E A / 2016 / 20371$

Editor(s):

(1) Peter A. Roussos, Lab. Pomology, Agricultural University of Athens, Greece. (2) Lanzhuang Chen, Laboratory of Plant Biotechnology, Faculty of Environment and Horticulture, Minami Kyushu University, Miyazaki, Japan. Reviewers:

(1) Moaed Almeselmani, General Commission for Scientific Agricultural Research, Syria. (2) Andrea Akemi Hoshino, UNESP, Brazil. (3) W. S. Jansen van Rensburg, Agricultural Research Council-Vegetable and Ornamental Plant Institute, Pretoria, South Africa. Complete Peer review History: http://sciencedomain.org/review-history/13304

Original Research Article

Received $24^{\text {th }}$ July 2015 Accepted $1^{\text {st }}$ February 2016 Published $14^{\text {th }}$ February 2016

\section{ABSTRACT}

DNA-based molecular markers such as Inter Simple Sequence Repeat (ISSR), Sequence-Related Amplified polymorphism (SRAP) and Random Amplified Polymorphic DNA (RAPD) were used in this study to examine the genetic differences among sixteen Iraqi wheat varieties. Seventy three primers out of 177 were reproducible and showed clear amplified bands. The degree of genetic diversity, Polymorphism information content (PIC) and resolving power (RP) were estimated. All the studied molecular markers were informative and showed good ability to classify and distinguish 16 wheat varieties. Total number of polymorphic bands is 134,221 and 55 for ISSR, SRAP and RAPD respectively. PIC and RP values were $0.259,0.264$ and 0.262 and $9.06,7.87$ and 2.78 
respectively. It seems that SRAP marker was the most optimal technique for characterization the of Iraqi wheat varieties. The most efficient primers were Ne ISSR 7 for ISSR; Me4-Em3 and Me4Em9 primers combination for SRAP; Operon primers K14, K15 and K19 for RAPD. The results of this study can be used to as starting point of the data base for Iraqi wheat varieties to be used in the future development of new varieties in a breeding programs.

Keywords: Wheat; genetic diversity; ISSR; SRAP; RAPD.

\section{INTRODUCTION}

Wheat (Triticum aestivum L.) is one of the most important cereals in the world and Iraq. The grain yield of wheat continued to increase, as a result of new varieties came under cultivation and the improved agricultural husbandry involving the use of chemical fertilizers. However, Iraq still imports tons of wheat every year. During the past several decades, the quality and yield of wheat have been gradually improved by traditional breeding methods. These methods have some restricting factors such as long time required and the limited gene pool that's available for wheat breeders. To increase wheat production in Iraq, it is a pre-requisite that local wheat germplasm should be characterized and classified by using new fast, easy and reliable technologies especially genetic markers [1]. Most researches all over the world nowadays depend on using molecular techniques [2]. Considerable efforts have been made to improve wheat crop productivity by using biotechnology. The morphological traits are greatly influenced by the environment, so diversity studies based on morphological traits may not be completely reliable, inaccurate and unreliable. Molecular diversity is independent of environmental influences because it is evaluated by using molecular markers and can be estimated by using DNA from any growth stage of the plant [3]. Genetic diversity can be considered the basis for genetic improvement, and knowledge of germplasm diversity has a significant impact on the improvement of wheat crop plants. According to modern breeding, it is suggested that genetic diversity in wheat is narrowed increasingly. Narrow genetic diversity is problematic in breeding for adaptation to biotic and abiotic stresses because there may not be sufficient variation to breed for greater yield under these stressful conditions. Therefore, it is necessary to investigate the genetic diversity in wheat germplasm to understand and in the future broaden the genetic variation available for breeding. Selection of diverse genotypes is a fundamental requirement in wheat breeding programs; this can only be obtained and utilized if gene pool of local and introduced germplasm has sufficient amount of genetic variability. Morphological traits can be used for assessing genetic diversity but are often influenced by the environment. For effective conservation and use of genetic resources, evaluation of genetic variation within collections could be dramatically enhanced by using DNA molecular markers. These DNA markers, when closely linked to genes of interest can be used to select for the desirable allele/s in a marker assisted breeding programs [4]. Therefore, in order to broaden the genetic variation in future wheat breeding it is necessary to investigate the genetic diversity in wheat germplasm [5]. Using molecular markers for the evaluation of genetic diversity is receiving much attention. Many scientists have investigated the genetic diversity in wheat crop using different molecular markers such as random amplified polymorphic DNA (RAPD), restriction fragment length polymorphism (RFLP), amplified fragment length polymorphism (AFLP), and inter simple sequence repeat (ISSR). PCRbased genomic polymorphism has been detected in cultivated hexaploid wheat (Triticum aestivum L.) by different markers such as microsatellite markers [6-8]. Inter Simple Sequence Repeat (ISSR) markers are also useful to detect genetic polymorphism in this species. Furthermore, one of the new types of molecular markers, Sequence-related amplified polymorphism (SRAP) was developed and used in wheat plant genetic studies. The goal of this study is to evaluate different DNA-based makers tehnologies for their ability to estimate the genetic diversity among 16 different Iraqi wheat varieties.

\section{MATERIALS AND METHODS}

\subsection{Plant Materials \& DNA Extraction}

Sixteen Iraqi wheat varieties were obtained from Iraqi Ministry of Agriculture (Table 1). The experiments were conducted at the Crop Research Laboratory, Dept. of Agronomy and Horticulture, University of Nebraska, USA. One hundred $\mathrm{mg}$ of 3 weeks old wheat seedling were collected in $2 \mathrm{ml}$ tubes and kept in $-80^{\circ} \mathrm{C}$ freezer. Plant tissues were dried by a freeze dryer (Vir 
Tis, Model\# FM $25 \mathrm{XL}-70$ ) for twenty four hours. A metal ball was put in each tube contained the lyophilized tissue. The leaf tissues were grinded by tissue lyzer II (Qiagen, Cat \# 85300) at speed $39 \mathrm{~S} / \mathrm{min}$ for $3 \mathrm{~min}$. The DNA extraction protocol was Adapted from [9].

\subsection{Primer Selection}

Sixteen Iraqi varieties were screened with ISSR [10], SRAP, and RAPD markers (kits K, L, M and N) (Operon Technology, Alameda, CA).

\subsubsection{ISSR primers}

Inter Simple Sequence Repeat (ISSR) technique is a PCR based method, which involves amplification of DNA segment present at an amplifiable distance in between two identical microsatellite repeat regions oriented in opposite direction. The technique uses microsatellites, usually 16-25 bp long, as primers in a single primer PCR reaction targeting multiple genomic loci to amplify mainly the inter- SSR sequences of different sizes [11].

Table 1. The wheat cultivars used in the study and their pedigree

\begin{tabular}{|c|c|c|}
\hline Symbol & Genotype & Pedigree \\
\hline A & Tamooz 2 & Mexipak / Saberbeg $\rightarrow$ (radiation) \\
\hline B & Iraq & \\
\hline C & Iba 99 & Ures/Bow s /3/Jup/Biy s /ures \\
\hline D & Rabee & Saberbeg / Hindia HDE831 \\
\hline $\mathrm{E}$ & Um Rabee & Jori69 / Haw \\
\hline $\mathrm{X}$ & Buhooth 22 & - \\
\hline G & Tamooz 3 & Mexipak /Saberbeg// Abu-ghurib $\rightarrow$ (radiation) \\
\hline $\mathrm{H}$ & Iba 95 & Veery S \\
\hline I & Dore 29 & \\
\hline $\mathrm{J}$ & Latifia & Australian line / Aras $\rightarrow$ (selection) \\
\hline Y & Dore 85 & \\
\hline S & Hashimia & Ecarda \\
\hline O & Fatih & - \\
\hline $\mathrm{P}$ & Abu Graib & Ajeeba / Inia 66R // Meico24 $\rightarrow$ (selection) \\
\hline M & Dijla & $\begin{array}{l}\mathrm{F}_{2} \text { materials derived from a commercial wheat breeding program, } \\
\text { USA } \rightarrow \text { (radiation) }\end{array}$ \\
\hline$N$ & Furat & $\begin{array}{l}\mathrm{F}_{2} \text { materials derived from a commercial wheat breeding program, } \\
\text { USA } \rightarrow \text { (radiation) }\end{array}$ \\
\hline
\end{tabular}

Table 2. ISSR primer sequences and their symbols

\begin{tabular}{|c|c|c|c|c|c|}
\hline $\begin{array}{l}\text { Primer } \\
\text { symbol }\end{array}$ & Primers & Sequences & $\begin{array}{l}\text { Primer } \\
\text { symbol }\end{array}$ & Primers & Sequences \\
\hline 3 & $\mathrm{Ne}$ ISSR 20 & $\begin{array}{l}\text { GATCTTCTTCTTC } \\
\text { TTCTTCTTCT }\end{array}$ & 7 & Ne ISSR 14 & $\begin{array}{l}\text { GATCCGGCGGCGG } \\
\text { CGGCGG }\end{array}$ \\
\hline 4 & $\mathrm{Ne}$ ISSR 10 & $\begin{array}{l}\text { CCCGGATCCGAG } \\
\text { AGAGAGAGA }\end{array}$ & 10 & Ne ISSR 17 & $\begin{array}{l}\text { GATCCAGCAGCAG } \\
\text { CAGCAG }\end{array}$ \\
\hline 5 & $\mathrm{Ne}$ ISSR 9 & $\begin{array}{l}\text { GCGATTATTATTA } \\
\text { TTATT }\end{array}$ & 12 & Ne ISSR 15 & $\begin{array}{l}\text { GATCTGGTGGTGG } \\
\text { TGGTGG }\end{array}$ \\
\hline 8 & $\mathrm{Ne}$ ISSR 7 & $\begin{array}{l}\text { AGCAGCAGCAGC } \\
\text { AGCGA }\end{array}$ & 16 & Ne ISSR 21 & $\begin{array}{l}\text { GATCTCTGTCTGTC } \\
\text { TGTCTGTCTG }\end{array}$ \\
\hline 6 & $\mathrm{Ne}$ ISSR 18 & $\begin{array}{l}\text { GATCATCATCATC } \\
\text { ATCATC }\end{array}$ & 18 & Ne ISSR 22 & $\begin{array}{l}\text { GATCAGTGAGTGA } \\
\text { GTGAGTGAGTG }\end{array}$ \\
\hline 1 & $\mathrm{Ne}$ ISSR 8 & $\begin{array}{l}\text { GGCGGCGGCGGC } \\
\text { TA }\end{array}$ & 19 & Ne ISSR 12 & $\begin{array}{l}\text { CCCGGATCCGTGTG } \\
\text { TGTGTGT }\end{array}$ \\
\hline 2 & $\mathrm{Ne}$ ISSR 19 & $\begin{array}{l}\text { GATCTTGTTGTTG } \\
\text { TTGTTG }\end{array}$ & 22 & Ne ISSR 11 & $\begin{array}{l}\text { CCCGGATCCCTCTC } \\
\text { TCTCTCT }\end{array}$ \\
\hline 9 & $\mathrm{Ne}$ ISSR 13 & $\begin{array}{l}\text { CCCGGATCCCACA } \\
\text { CACACACA }\end{array}$ & 20 & $\mathrm{Ne}$ ISSR 3 & $\begin{array}{l}\text { GAGAGAGAGAGAG } \\
\text { AGATC }\end{array}$ \\
\hline 11 & $\mathrm{Ne}$ ISSR 16 & $\begin{array}{l}\text { GATCGAGGAGGA } \\
\text { GGAGGAG }\end{array}$ & 14 & $\mathrm{Ne}$ ISSR 6 & $\begin{array}{l}\text { AAGAAGAAGAAGA } \\
\text { AGTG }\end{array}$ \\
\hline 13 & $\mathrm{Ne}$ ISSR 4 & $\begin{array}{l}\text { CACACACACACA } \\
\text { CACAGT }\end{array}$ & 15 & $\mathrm{Ne}$ ISSR 5 & $\begin{array}{l}\text { AAGAAGAAGAAGA } \\
\text { AGGC }\end{array}$ \\
\hline
\end{tabular}




\subsubsection{SRAP Primers}

Sequence-related amplified polymorphism (SRAP) markers are based on two primer amplification, which preferentially amplifies open reading frames (ORFs) or coding regions that result in a number of dominant and codominant markers. (Table 3 shows the combinations of the SRAP primers [12] that produced polymorphic bands.

\subsection{Polymerase Chain Reaction}

The PCR mixture $(25 \mu \mathrm{l}$ total) consisted of 50 $\mathrm{mM} \mathrm{KCl}$ and $10 \mathrm{mM}$ Tris- $\mathrm{HCl}(\mathrm{pH}$ 8.8), $2 \mathrm{mM}$ $\mathrm{MgCl}_{2}, 125 \mathrm{mM}$ of dNTP, $50 \mathrm{ng}$ of each primer, 1.0 unit of Taq DNA polymerase, and $60 \mathrm{ng}$ of genomic DNA. Amplification was carried out in C 1000 Touch $^{\text {TM }}$ Thermal Cycler (Bio-Rad) using a program that consisted of initial denaturation for $3 \mathrm{~min}$. at $9^{\circ} \mathrm{C}$, followed by 34 cycle of $1 \mathrm{~min}$. at $94^{\circ} \mathrm{C}, 1 \mathrm{~min}$ at 45 to $55^{\circ}$ (depending on the primers), and $1 \mathrm{~min}$. at $72^{\circ} \mathrm{C}$, and final extension for $10 \mathrm{~min}$. The amplified reaction mixtures were stored at $4^{\circ} \mathrm{C}$ until they were gel- fractionated on either polyacrylamide gel, or agarose gel (depending on the molecular technique).

\subsection{Electrophoreses}

The amplified reaction mixtures of SSR, SRAP, and ISSR were gel- fractionated on $12 \%(\mathrm{w} / \mathrm{v})$ polyacrylamide gel (37crylamide: 1bisacrrylamide) in 1X DGGE buffer (40 mM Tris$\mathrm{HCl}, 20 \mathrm{mM}$ sodium acetate, $1 \mathrm{mM}$ EDTA) in vertical gel apparatus (Hofer Scientific Instrument, SE600) at $300 \mathrm{~V}$ for $3 \mathrm{~h}$. The buffer temperature was controlled by a circulating bath with the temperature set to $20^{\circ} \mathrm{C}$. Gels were stained in ethidium bromide $(1 \mathrm{mg} / \mathrm{mL})$ for 20 min, de-stained in deionized water for $1 \mathrm{~h}$, and then photographed by means of Gel Doc 2000 (Bio-Red).

The amplified products of RAPD primers Electrophoresed in 1\% agarose gel with $1 \mathrm{X}$ TBE buffer, and $2 \mu \mathrm{l}$ of ethidium bromide using 70 volts. The amplified markers were photographed by Gel Doc 2000 (Bio-Red).

\subsection{Statistical Analysis}

Data were collected and scored for the presence (1) or absence (0) of amplified bands. The genetic similarity coefficients for each pairwise of varieties were calculated by using software $R$ (version 3. 0.1 (2013-05-16) Copyright (C) 2013 The $R$ Foundation for Statistical Computing Platform: i386-w64-mingw32/i38).

Resolving power (RP) was calculated according to the following equation;

$$
P=\Sigma 1-\left(2^{*}(0.5-f)\right)
$$

Where $f$ is the frequencies and $P$ is polymorphism

Polymorphism information content (PIC) values were obtained using the following formula:

$$
\mathrm{PIC}=1-\Sigma \mathrm{Pij} 2 .
$$

Where as Pij is the frequency of jth allele of ith locus, summed across all the alleles for the locus over all lines. A PIC value $>0.5$ is considered as being highly informative marker while $0.5>\mathrm{PIC}>$ 0.25 is an informative marker, and PIC is 0.25 a slightly informative marker [13].

Table 3. Combination of the SRAP primers with their symbols that was screened and amplified

\begin{tabular}{llllll}
\hline $\begin{array}{l}\text { Symbol of } \\
\text { combination }\end{array}$ & Me & Em & $\begin{array}{l}\text { Symbol of } \\
\text { combination }\end{array}$ & Me & Em \\
\hline 31 & me 2 & em 1 & 52 & me 4 & em 10 \\
32 & me 2 & em 2 & 53 & me 4 & em 11 \\
33 & me 3 & em 3 & 54 & me 4 & em 12 \\
34 & me 3 & em 4 & 8 & me 1 & em8 \\
43 & me 3 & em 1 & 9 & me 1 & em9 \\
44 & me 3 & em 2 & 12 & me 1 & em12 \\
45 & me 4 & em 3 & 19 & me 2 & em4 \\
46 & me 4 & em 4 & 21 & me 2 & em6 \\
48 & me 4 & em 6 & 22 & me 2 & em7 \\
49 & me 4 & em 7 & 23 & me 2 & em8 \\
50 & me 4 & em 8 & 26 & me 2 & em11 \\
51 & me 4 & em 9 & 27 & me 2 & em12 \\
25 & me 2 & em10 & 4 & me 1 & em4 \\
3 & me 1 & em3 & 15 & me 1 & em16 \\
\hline
\end{tabular}




\section{RESULTS AND DISCUSSION}

\subsection{ISSR Marker}

Twenty ISSR primers yielded in total 167 bands of which 134 were polymorphic (Table 4) with average percentage of polymorphism $80.24 \%$. Amplified bands per primer ranged from 2 (primer 11) to 26 bands (Primer 8) with an average of 8.4 bands. The level of polymorphism per primer ranged from 50 up to $100 \%$. Primer 8 showed the highest number of amplified bands with the highest number of polymorphic bands. PIC values ranged from very low value of primer $4(0.059)$ to high values $(0.467$ and 0.420$)$ of primers 2 and 15 respectively, and the average was 0.259, referring that this technique is informative in genetic diversity [13]. RP value ranged from 1.13 to 33.00 with an average of 9.06 per primer. The highest RP was recorded by the primer 8 followed by the primer 18 referring to their importance in genetic diversity, because of RP positive correlation with the total amplified bands [14].

Primers with di-nucleotide repeat produced low level of polymorphism in most primers used in this study in comparison with tri- nucleotide and tetra- nucleotide primers specially the di- nucleotide with GA repeats. Tri- nucleotide primers with repeats AGC and ATC showed the highest number of polymorphic bands. These results are in agreement with those of [15-17] who confirmed that di-nucleotide repeat primers were found at lower polymorphic levels.

According to PIC and RP values, the results revealed efficiency of primer 8 which has consist of tri-nucleotides repeats (TTG \& AGC). In spite of that tri-nucleotides repeats show in low frequency as compare to di-nucleotides $[18,19]$ TTG \& AGC seem useful in characterization the Iraqi wheat varieties.

\subsubsection{SRAP}

The analysis of the 16 local varieties with 28 SRAP primer combinations identified a total of 248 bands (Table 5), among them 221 were polymorphic (87.56\%). Between 3 and 19 bands were amplified per primer combination with an average of 8.86 bands. The number of polymorphic bands for each primer combination varied from 3 to 17 with an average of 7.9. Primer combination 43 appeared with the highest number of bands and all of them were polymorphic, followed by the two primer combination 31 and 49 which yielded in 17

Table 4. Performance of the ISSR primers used to screen the Iraqi varieties

\begin{tabular}{lllllll}
\hline Primer & $\begin{array}{l}\text { No of } \\
\text { alleles (A) }\end{array}$ & Monomorphic & $\begin{array}{l}\text { Polymorphic } \\
\text { bands (B) }\end{array}$ & A / B\% & PIC & RP \\
\hline 3 & 3 & 0 & 3 & 100.00 & 0.385 & 2.75 \\
4 & 4 & 2 & 2 & 50.00 & 0.059 & 4.25 \\
5 & 5 & 0 & 5 & 100.00 & 0.195 & 1.13 \\
8 & 26 & 5 & 21 & 80.77 & 0.296 & 33.00 \\
6 & 17 & 2 & 15 & 88.24 & 0.281 & 16.13 \\
1 & 4 & 0 & 4 & 100.00 & 0.301 & 3.50 \\
2 & 4 & 0 & 4 & 100.00 & 0.467 & 3.88 \\
9 & 4 & 0 & 4 & 100.00 & 0.232 & 5.13 \\
11 & 2 & 1 & 1 & 50.00 & 0.152 & 3.63 \\
13 & 3 & 0 & 3 & 100.00 & 0.318 & 1.25 \\
15 & 7 & 0 & 7 & 100.00 & 0.420 & 6.00 \\
7 & 9 & 3 & 6 & 66.67 & 0.213 & 14.38 \\
10 & 7 & 0 & 7 & 100.00 & 0.366 & 7.50 \\
12 & 4 & 0 & 4 & 100.00 & 0.361 & 3.63 \\
16 & 14 & 5 & 9 & 64.29 & 0.167 & 18.13 \\
18 & 15 & 6 & 9 & 60.00 & 0.227 & 20.63 \\
19 & 7 & 1 & 6 & 85.71 & 0.219 & 4.75 \\
22 & 6 & 1 & 5 & 83.33 & 0.247 & 7.00 \\
20 & 9 & 4 & 5 & 55.56 & 0.158 & 11.75 \\
14 & 17 & 3 & 14 & 82.35 & 0.108 & 12.75 \\
Sum & 167 & 33 & 134 & 80.24 & & 181.13 \\
Aver. & 8.35 & 1.65 & 6.7 & 80.24 & 0.259 & 9.06 \\
\hline
\end{tabular}


Table 5. Performance of the SRAP primer combinations used to screen the Iraqi wheat varieties

\begin{tabular}{lllllll}
\hline Markers & No of alleles (A) & Monomorphic & $\begin{array}{l}\text { Polymorphic } \\
\text { (B) }\end{array}$ & A /B \% & RP & PIC \\
\hline 31 & 17 & 0 & 17 & 100.00 & 9.88 & 0.353 \\
32 & 3 & 0 & 3 & 100.00 & 0.63 & 0.185 \\
33 & 4 & 1 & 3 & 75.00 & 2.88 & 0.178 \\
34 & 5 & 0 & 5 & 100.00 & 1.13 & 0.195 \\
43 & 19 & 0 & 19 & 100.00 & 16.88 & 0.403 \\
44 & 11 & 3 & 8 & 72.73 & 14.63 & 0.224 \\
45 & 8 & 1 & 7 & 87.50 & 8.38 & 0.222 \\
46 & 7 & 1 & 6 & 85.71 & 6.75 & 0.234 \\
48 & 15 & 1 & 14 & 93.33 & 19.00 & 0.363 \\
49 & 17 & 0 & 17 & 100.00 & 11.63 & 0.328 \\
50 & 14 & 4 & 10 & 71.43 & 18.00 & 0.208 \\
51 & 8 & 2 & 6 & 75.00 & 9.88 & 0.277 \\
52 & 7 & 1 & 6 & 85.71 & 7.25 & 0.368 \\
53 & 15 & 0 & 15 & 100.00 & 9.88 & 0.329 \\
54 & 12 & 1 & 11 & 91.67 & 12.63 & 0.309 \\
8 & 7 & 0 & 7 & 100.00 & 3.88 & 0.242 \\
9 & 7 & 0 & 7 & 100.00 & 5.00 & 0.205 \\
12 & 6 & 0 & 6 & 100.00 & 4.50 & 0.372 \\
19 & 9 & 2 & 7 & 77.78 & 8.25 & 0.238 \\
21 & 5 & 0 & 5 & 100.00 & 4.50 & 0.388 \\
22 & 6 & 2 & 4 & 66.67 & 6.25 & 0.255 \\
23 & 6 & 3 & 3 & 50.00 & 8.00 & 0.076 \\
26 & 8 & 2 & 6 & 75.00 & 7.00 & 0.135 \\
27 & 4 & 1 & 3 & 75.00 & 5.25 & 0.355 \\
25 & 7 & 1 & 6 & 85.71 & 3.75 & 0.188 \\
3 & 6 & 1 & 11 & 83.33 & 6.88 & 0.205 \\
4 & 11 & 0 & 4 & 100.00 & 5.63 & 0.265 \\
15 & 4 & 0 & 7.893 & 87.00 & 2.00 & 0.305 \\
SUM & 248 & 27 & 87.56 & 7.87 & 0.264 \\
\hline & 8.857 & 0.964 & & & & \\
\hline
\end{tabular}

bands for each, both of them were polymorphic $100 \%$. Primer combination number 23 recorded very low value of PIC, but the values in most of other primers were high and reliable. The highest value was recorded by primer combination number 43 (0.403). The average was 0.264 meaning that this is also informative and reliable in explaining genetic diversity and calculating the distances between Iraqi wheat varieties. RP ranged from 0.63 (primer combination 32) to 19.00 (primer combination 48) with average 7.87. The results revealed that primers combination 43 followed by 49 and 31 were useful to characterize the Iraqi wheat varieties due to them scores of the produced bands, polymorphic bands, RP and PIC.

\subsubsection{RAPD}

Twenty five RAPD primers were chosen as they yielded polymorphic bands. In total 59 bands were amplified and 55 of them were polymorphic with an average of $94 \%$ (Table 6). The number of polymorphic bands per primer ranged from 1 to 4 with an average of 2.2 bands. The level of polymorphism per primer was mostly 100\%, except for the primers L12 and M10; it was 50\% for each. Primers: k9, k14, k15, and k16 showed higher number of amplified bands (4), all of them were polymorphic. The highest value of PIC was 0 . 492, recorded by the primers $\mathrm{K} 10$ and L9 followed by other high values recorded by primers M11, L9, and K15. The average of PIC values was 0.262 . These values mean that this technique is informative and can be used reliably in genetic diversity clustering. RAPD primers, in general, showed less values of RP than other techniques, as the average was 2.85 , the maximum value was 7.00 (K16) and the minimum value was 0.50 (O9). Primer K15, K14 and K 19 own best combination primers of polymorphism, RP and PIC values, therefore 
they look optimal primers for characterization the Iraqi wheat varieties. However, the RAPD technique is not efficient as compare with other techniques since it amplification is random. The current results supported this fact since the RAPD technique own less values of RP as compare to other techniques.

\subsection{Number of DNA Alleles}

Table 7 reveals the differences among the wheat varieties according to the number of bands they produced as a result of scoring with primers of different molecular techniques. Variety $\mathrm{H}$ produced the highest number of band among Iraqi varieties (154 bands with percent 62.28) when they were scored by ISSR primers. In SRAP technique variety $\mathrm{H}$ achieved 67.74 percent of all primer combination used in this technique. It produced 104 bands. In RAPD technique, $H$ variety also gave the highest number of bands (48 bands with percent $81.36 \%$ ). There were other more varieties that had high number of bands from the last three techniques such as variety $\mathrm{A}$ and $\mathrm{N}$. Varieties that produced higher number of band than other are consider more important for researchers in breeding programs.

\subsection{Genetic Diversity}

\subsubsection{ISSR}

The data clustered the 16 varieties into three main groups (Fig. 1); first group included four varieties ( $\mathrm{G}, \mathrm{H}, \mathrm{N}$, and $\mathrm{A})$. The similarity among them ranged from 0.7108 , between $\mathrm{N}$ and $\mathrm{H}$ varieties, to 0.7952 , between $A$ and $N$ varieties. Second group contained three sub clusters each of them contained two varieties. The highest value of coefficient similarity was 0.9277 , between $S$ and $D$ varieties, followed by the similarity coefficient between $\mathrm{I}$ and $\mathrm{E}$ varieties (0.8434), then by $Y$ and $O$ varieties (0.7892). Third group contained six varieties. $J$ and $C$ formed a separate sub cluster, the similarity coefficient between them was 0.8855 , and each of others was alone in a separate cluster.

Table 6. Performance of the RAPD primers with Iraqi varieties

\begin{tabular}{lllllll}
\hline Primers & $\begin{array}{l}\text { No of Allels } \\
(\mathbf{A})\end{array}$ & Monomorphic & $\begin{array}{l}\text { Polymorphic } \\
\text { bands (B) }\end{array}$ & A / B \% & RP & PIC \\
\hline OP N-05 & 1 & 0 & 1 & 100 & 0.13 & 0.117 \\
OP K-16 & 4 & 0 & 4 & 100 & 7.00 & 0.219 \\
OP K-15 & 4 & 0 & 4 & 100 & 5.50 & 0.426 \\
OP K-8 & 3 & 0 & 3 & 100 & 2.13 & 0.185 \\
OP K-9 & 4 & 0 & 4 & 100 & 2.13 & 0.189 \\
OP K-10 & 1 & 0 & 1 & 100 & 0.88 & 0.492 \\
OP K-6 & 2 & 0 & 2 & 100 & 3.75 & 0.117 \\
OP K-12 & 2 & 0 & 2 & 100 & 1.88 & 0.262 \\
OP K-11 & 3 & 0 & 3 & 100 & 3.88 & 0.117 \\
OP K-14 & 4 & 0 & 4 & 100 & 4.00 & 0.336 \\
OP K-20 & 3 & 0 & 3 & 100 & 3.25 & 0.328 \\
OP K-19 & 3 & 0 & 3 & 100 & 4.13 & 0.393 \\
OP M-9 & 1 & 0 & 1 & 100 & 1.38 & 0.430 \\
OP L-6 & 3 & 0 & 3 & 100 & 3.25 & 0.318 \\
OP L-9 & 1 & 0 & 1 & 100 & 1.13 & 0.492 \\
OP L-13 & 3 & 0 & 3 & 100 & 5.63 & 0.117 \\
OP L-12 & 2 & 1 & 1 & 50 & 3.75 & 0.109 \\
OP M-8 & 2 & 0 & 2 & 100 & 3.75 & 0.117 \\
OP M-6 & 2 & 0 & 2 & 100 & 3.75 & 0.117 \\
OP M-11 & 1 & 0 & 1 & 100 & 1.25 & 0.469 \\
OP M-16 & 2 & 0 & 2 & 100 & 1.38 & 0.355 \\
OP N-07 & 1 & 0 & 1 & 100 & 1.88 & 0.117 \\
OP N-08 & 2 & 0 & 2 & 100 & 2.00 & 0.117 \\
OP O-9 & 1 & 0 & 1 & 100 & 0.50 & 0.375 \\
OP M-10 & 2 & 1 & 1 & 50 & 2.88 & 0.246 \\
Sum & 57 & 2 & 55 & 2400 & 71.13 & 6.562 \\
& 2.28 & 0.08 & 2.2 & 96.491 & 2.85 & 0.262 \\
\hline
\end{tabular}


Table 7. Number and percentage of bands from different marker system per variety

\begin{tabular}{lllllllll}
\hline V & \multicolumn{2}{c}{ ISSR } & \multicolumn{2}{c}{ SRAP } & \multicolumn{2}{c}{ RAPD } & Total & Average bands \\
\cline { 2 - 7 } & No & $\%$ & No & $\%$ & No & $\%$ & bands & \\
\hline A & 94 & 56.29 & 148.00 & 59.68 & 43.00 & 72.88 & 285 & 95 \\
B & 98 & 58.68 & 86.00 & 34.68 & 37.00 & 62.71 & 221 & 74 \\
C & 91 & 54.49 & 78.00 & 31.45 & 39.00 & 66.10 & 208 & 69 \\
D & 99 & 59.28 & 120.00 & 48.39 & 40.00 & 67.80 & 259 & 86 \\
E & 79 & 47.31 & 119.00 & 47.98 & 33.00 & 55.93 & 231 & 77 \\
G & 98 & 58.68 & 126.00 & 50.81 & 44.00 & 74.58 & 268 & 89 \\
H & 104 & 62.28 & 168.00 & 67.74 & 48.00 & 81.36 & 320 & 107 \\
I & 79 & 47.31 & 108.00 & 43.55 & 33.00 & 55.93 & 220 & 73 \\
J & 90 & 53.89 & 99.00 & 39.92 & 41.00 & 69.49 & 230 & 77 \\
M & 84 & 50.30 & 72.00 & 29.03 & 15.00 & 25.42 & 171 & 57 \\
N & 92 & 55.09 & 147.00 & 59.27 & 46.00 & 77.97 & 285 & 95 \\
O & 85 & 50.90 & 80.00 & 32.26 & 24.00 & 40.68 & 189 & 63 \\
P & 82 & 49.10 & 86.00 & 34.68 & 37.00 & 62.71 & 205 & 68 \\
S & 99 & 59.28 & 107.00 & 43.15 & 41.00 & 69.49 & 247 & 82 \\
X & 91 & 54.49 & 102.00 & 41.13 & 41.00 & 69.49 & 234 & 78 \\
Y & 84 & 50.30 & 116.00 & 46.77 & 39.00 & 66.10 & 239 & 80 \\
\hline
\end{tabular}

The similarity coefficients between each pair of them were 0.6687 between $M$ and $X, 0.6627$ between $\mathrm{M}$ and $\mathrm{B}, 0.7108$ between $\mathrm{M}$ and $\mathrm{P}$, 0.698795 between $M$ and $\mathrm{J}, 0.789157$ between $X$ and $B, 0.813253$ between $X$ and $P, 0.825301$ between $X$ and $\mathrm{J}, 0.831325$ between $\mathrm{B}$ and $\mathrm{P}$, 0.831325 between $\mathrm{B}$ and $\mathrm{J}$, and 0.855422 between $\mathrm{P}$ and $\mathrm{J}$.

\subsubsection{SRAP}

Scoring twenty eight SRAP primer combinations showed similarity among sixteen Iraqi wheat varieties ranged from 0.498 to 0.850 . The dendogram (Fig. 2) revealed three major clusters of wheat varieties. Cluster one contained four varieties (G, $H, N$, and $A)$. The similarity coefficient between $\mathrm{N}$ and $\mathrm{A}$, the highest value among varieties in this cluster, was 0.745 . The other coefficients among them were 0.636 between $G$ and $H$ varieties, 0.640 between $G$ and $\mathrm{N}$ varieties, 0.660 between $\mathrm{G}$ and $\mathrm{A}$ varieties, and 0.672 between $\mathrm{H}$ and $\mathrm{N}$ varieties. Cluster two contained six varieties divided into three sub clusters. O represented a sub-cluster, while $B$ and $C$ represented second sub cluster with similarity coefficient about 0.838 . Third sub cluster included $\mathrm{M}, \mathrm{J}$, and $\mathrm{P}$. The similarity coefficients between them were 0.850 between $\mathrm{M}$ and $\mathrm{J}$ varieties, 0.822 between $\mathrm{M}$ and $\mathrm{P}$, and 0.850 between $\mathrm{J}$ and $\mathrm{P}$. Cluster three included two sub clusters, first one included E, Y, and I. The similarity coefficients between them were 0.834 between $E$ and $Y$ varieties, 0.834 between $E$ and I, and 0.846 between $Y$ and I varieties. The last sub cluster contained X, S, and D. Similarity coefficient between $X$ and $S$ varieties was 0.802 , and between $X$ and $D$ was 0.765 , whereas between $S$ and $D$ was 0.802 .

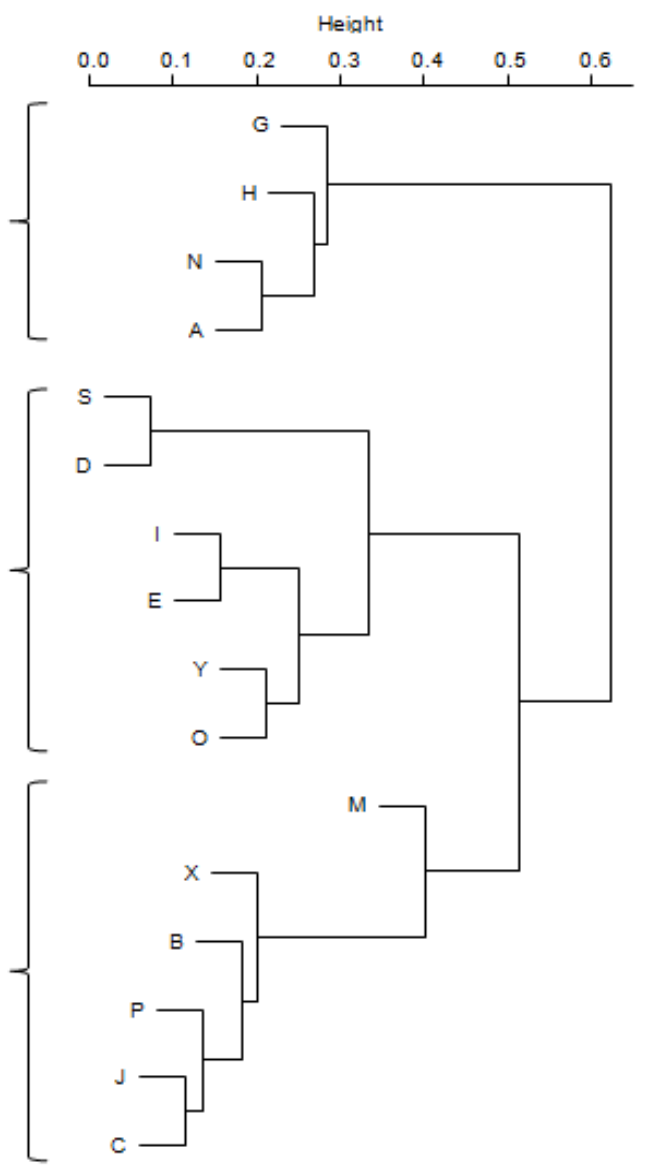

Fig. 1. Dendrogram of 18 wheat cultivars from Iraq based on ISSR markers 


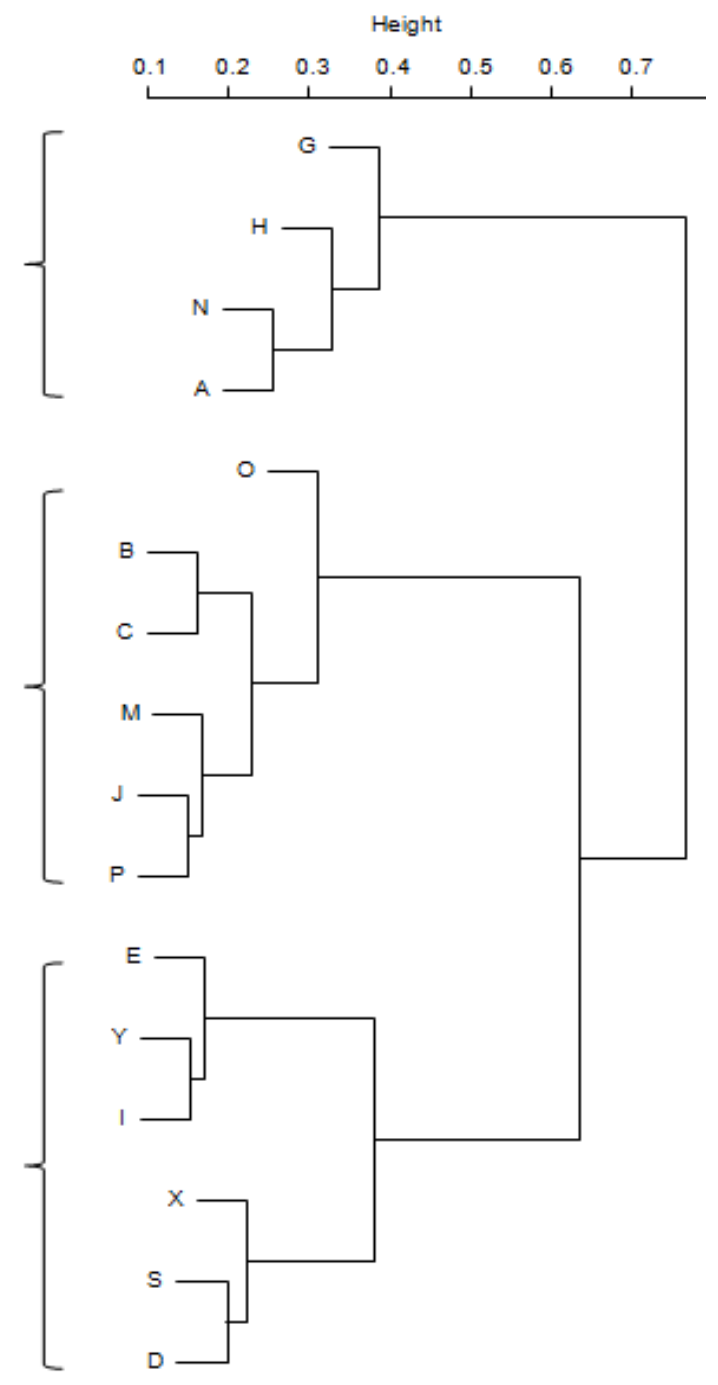

Fig. 2. Dendrogram of 18 wheat cultivars from Iraq based on SRAP markers

\subsubsection{RAPD}

Similarity coefficient among sixteen Iraqi varieties depending on twenty seven RAPD primers ranged from 0.339 to 0.983 . Cluster dendrogram classified the evaluated varieties into four clusters (Fig. 3). The variety $\mathrm{M}$ alone formed the first cluster having less similarity with each of other varieties. Second cluster involved five varieties divided into two sub clusters. First sub cluster contained $C$ and $X$ varieties with similarity coefficient 0.966 between them. Second sub cluster contained three members $\mathrm{B}, \mathrm{J}$ and $\mathrm{P}$. The highest similarity coefficient among them was 0.932 between the each pairwise of $\mathrm{J}$ and $\mathrm{P}$; $\mathrm{B}$ and $P$ varieties, followed by $B$ and $J$. Third cluster included $\mathrm{O}, \mathrm{I}$, and $\mathrm{E}$. The similarity coefficients between each pairwise were 0.780 between $O$ and I varieties, 0.780 between $O$ and $\mathrm{E}$ varieties, and 0.898 between I and E. Fourth cluster contained two sub clusters. First sub cluster contained four varieties ( $\mathrm{Y}, \mathrm{N}, \mathrm{S}$, and $\mathrm{D})$. The highest value of similarity coefficient among all varieties (0.983) was between $S$ and $D$ varieties. Similarity coefficient between other members of this sub cluster were 0.780 between $\mathrm{Y}$ and $\mathrm{N}$ varieties, 0.864 between $\mathrm{Y}$ and $\mathrm{S}$ varieties, and 0.915 between $\mathrm{Y}$ and $\mathrm{S}$. G, $\mathrm{H}$, and A formed the last sub cluster. Similarity coefficient between $\mathrm{G}$ and $\mathrm{H}$ variety was 0.797 between $G$ and $H$ varieties, 0.712 between $G$ and $A$, finally 0.814 between $H$ and $A$.

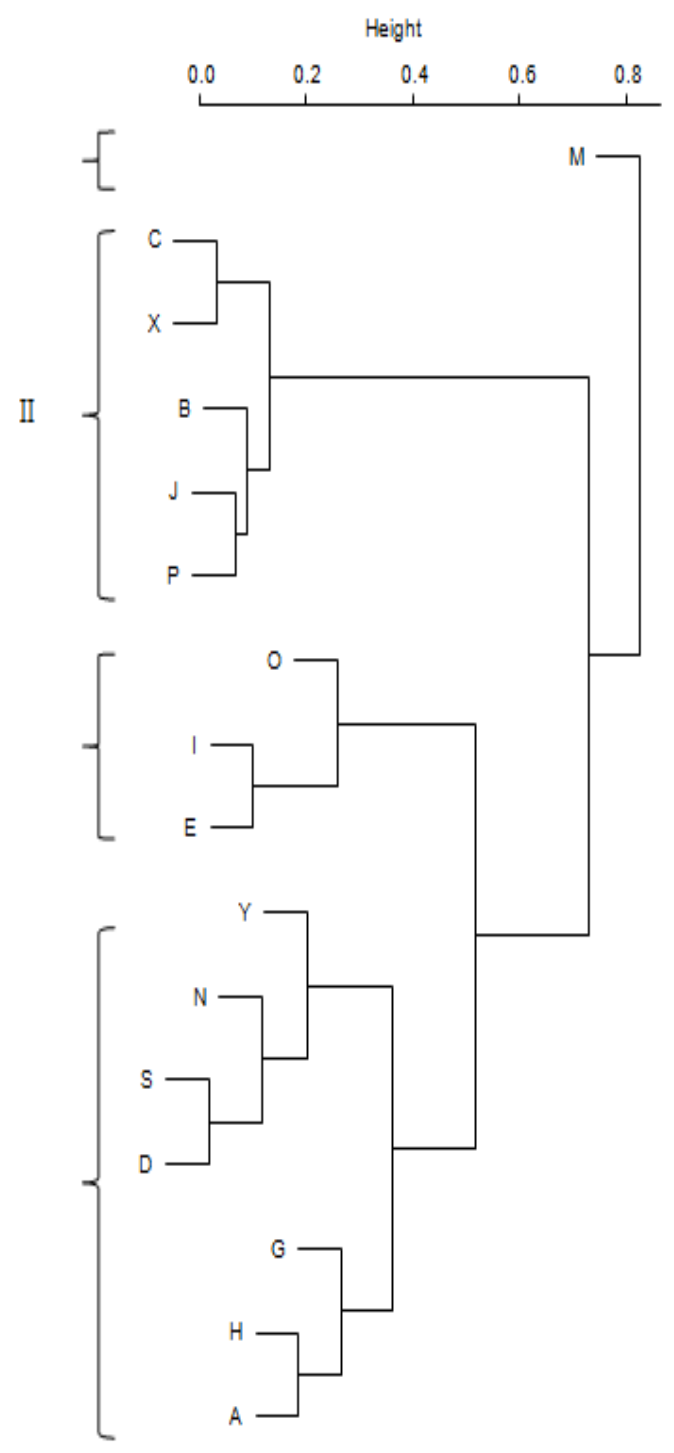

Fig. 3. Dendrogram of 18 wheat cultivars from Iraq based on RAPD markers 


\section{CONCLUSION}

The rapidly developing technology of DNA markers helps to open a new real possibility for evolving functional markers as reliable genetic markers for genetic improvement. Varieties $\mathrm{H}, \mathrm{A}$ and $\mathrm{N}$ were the most responsive genotypes to the used primers due to own highest numbers of polymorphism bands (Table 7). Some varieties remain together across the produced dendograms that have been built on various markers. The varieties $\mathrm{G}$ and $\mathrm{H}, \mathrm{S}$ and $\mathrm{D}, \mathrm{J}$ and $P$ were stayed in same clusters across all markers. While I, E and $\mathrm{y} ; \mathrm{M}, \mathrm{B}$ and $\mathrm{C}$; and $\mathrm{N}$ and $A$ gathered in same cluster across ISSR and SRAP markers. That would be useful for breeders in breeding schemes in term of developing the local varieties [20]. All the studied molecular markers were informative and showed good ability to classify the wheat varieties. Despite the declining popularity of RAPD markers technology, it is very easy to perform with low cost. According to total number of the produced bands, Average number of polymorphic bands per primer, RP and PIC values, SRAP marker seem to be the suitable technique for characterization the Iraqi wheat varieties. Finally, the information resulted from this study can be used to contribute in putting the core stone of the data base for Iraqi wheat varieties to be used in the future as an indicator for breeding programs because the exclusive use of local genotypes make the work difficult for the breeder [6], so interest should be in the introduction of elite and new genetic materials to constantly enhance the productivity and quality of the characteristics for the local genotypes. Continuous diversification of plant breeding materials is warranted to ensure that the plant improvement continues to be sustainable in the future. Developing effective indicators for genetic diversity of cultivated plants not only enhances the monitoring of genetic changes in improved gene pools, but also the effort of germplasm conservation and Utilization. The three different DNA-based markers (ISSR, SRAP, and RAPD) were similar in their ability to group the 16 different Iraqi wheat varieties into similar grouping.

\section{COMPETING INTERESTS}

Authors have declared that no competing interests exist.

\section{REFERENCES}

1. Galovic V, Dengic $S$, Jelovac $D$. Determination of polymorphism of microsatellite primers in hexaploid wheat. Genetika. 2005;37:217-223.

2. Repkova J, Dreiseitl A. Candidate markers for powdery mildew resistance genes from wild barley PI284752. Euphytica. 2010; 175:283-292

3. Tatikonda L, Wani SP, Kannan S, Beerelli $\mathrm{N}$, Sreedevi TK, Hoisington DA, Devi $\mathrm{P}$, Varshney RA. AFLP-based molecular characterization of an elite germplasm collection of Jatropha curcas L., a biofuel plant. Plant Sci. 2009;176:505-513.

4. Zeb B, Ahmad Khan I, Ali S, Bacha S, Mu S, Swati ZA. Study on genetic diversity in Pakistani wheat varieties using Simple Sequence Repeat (SSR) markers. African J. Biotechnol. 2009;8:4016-4019.

5. Mohammadi SA, Prasanna BM. Analysis of genetic diversity in crop plant-salient statistical tools and considerations. Crop Sci. 2003;43:1235-1248.

6. Hamdalla MS. Assess the degree of genetic divergence among sixteen complexes genetically wheat bread using SSR indicators. International Journal of Scientific \& Technology Research. 2014;3: 19-23.

7. Akkaya MS, Buyukunal-Bal EB. Assessment of genetic variation of bread wheat varieties using microsatellite markers. Euphytica. 2004;135:179-185.

8. Dograr N, Akin-Yalin S, Akkaya M. Discriminating durum wheat cultivars using highly polymorphic simple sequence repeat DNA markers. Plant Breed. 2000;119:360-362.

9. Xin Z, Chen J. A high throughput DNA extraction method with high yield and quality. Plant Methods. 2012;8:26.

10. Ammiraju JS, Dholakia BB, Santra DK, Singh H, Lagu MD, Tamhankar SA, Dhaliwal HS, Rao VS, Gupta VS, Ranjekar PK. Identification of Inter Simple Sequence Repeat (ISSR) markers associated with seed size in wheat. Theor. Appl. Genet. 2001;102:726-732.

11. Zietkiewicz E, Rafalski A, Labuda D. Genome fingerprinting by Simple Sequence Repeat (SSR) - Anchored polymerase chain reaction amplification. Genomics. 1994;20:176-183.

12. Pedrasa F, Specht J, Dweikat I. A new PCR-based linkage map in pearl millet. Crop Sci. 2010;50:1754-1760.

13. Botstein D, White RL, Skolnick M, Davis RW. Construction of a genetic linkage map 
in man using restriction fragment length polymorphisms. Am. J. Hum. Genet. 1980; 32:314-331.

14. Najaphy A, Parchin RA, Farshadfar E. Evaluation of genetic diversity in wheat cultivars and breeding lines using Inter Simple Sequence Repeat Markers. Biotechnology \& Biotechnological Equipment. 2011;25:2634-263.

15. El-Assal S, Gaber A. Discrimination capacity of RAPD, ISSR and SSR markers and of their effectiveness in establishing genetic relationship and diversity among Egyptian and Saudi wheat cultivars. American Journal of Applied Sciences. 2012;9:724-735. ISSN 1546-9239.

16. Akkaya MS, Bhagwat AA, Cregan PB. Length polymorphisms of simple sequence repeat DNA in soybean. Genetics. 1992; 132:1131-1139.

17. Sofalian O, Chaparzadeh N, Javanmard A, Hejazi MS. Study of the genetic diversity of wheat landraces from Northwest of Iran based on ISSR molecular markers. International Journal of Agriculture \& Biology. 2008;10:466468.

18. Blair MW, Panaud O, McCouch SR. InterSimple Sequence Repeats (ISSR) amplification for analysis of microsatellite motif frequency and fingerprinting in rice (Oryza sativa L). Theor. Appl. Genet. 1999;98:780-792.

19. Joshi SP, Gupta VS, Aggarwal RK, Ranjekar PK, Brar DS. Genetic diversity and phylogenetic relationship as revealed by Inter-Simple Sequence Repeat (ISSR) polymorphism in the genus Oryza. Theor. Appl. Genet. 2000;100:1311-1320.

20. Wang ML, Barkley NA, Jenkins TM. Microsatellite markers in plants and insects: Application of biotechnology. Genes, Genomes and Genomics. 2009; 3(special issue 1):54-67.

(c) 2016 Al-Kaab et al.; This is an Open Access article distributed under the terms of the Creative Commons Attribution License (http://creativecommons.org/licenses/by/4.0), which permits unrestricted use, distribution, and reproduction in any medium, provided the original work is properly cited.

Peer-review history:

The peer review history for this paper can be accessed here: http://sciencedomain.org/review-history/13304 